Research Article

\title{
Atmospheric Nitrogen Deposition Associated with the Eutrophication of Taihu Lake
}

\author{
Xi Chen $\mathbb{D}^{1},{ }^{1}$ Yan-hua Wang $\mathbb{D},{ }^{1,2}$ Chun Ye, ${ }^{3}$ Wei Zhou, ${ }^{4}$ Zu-cong Cai, ${ }^{1,2}$ Hao Yang, ${ }^{1,2}$ \\ and Xiao Han ${ }^{5,6}$ \\ ${ }^{1}$ School of Geography Science, Nanjing Normal University, Nanjing 210023, China \\ ${ }^{2}$ Jiangsu Center for Collaborative Innovation in Geographical Information Resource Development and Application, \\ Nanjing 210023, China \\ ${ }^{3}$ Chinese Research Academy of Environmental Sciences, Beijing 100012, China \\ ${ }^{4}$ Institute of Soil Science, Chinese Academy of Sciences, Nanjing 210008, China \\ ${ }^{5}$ State Key Laboratory of Atmospheric Boundary Layer Physics and Atmospheric Chemistry, Institute of Atmospheric Physics, \\ Chinese Academy of Sciences, Beijing 100029, China \\ ${ }^{6}$ College of Earth Science, University of Chinese Academy of Sciences, Beijing 100049, China
}

Correspondence should be addressed to Yan-hua Wang; wangyanhua@njnu.edu.cn

Received 18 March 2018; Revised 30 May 2018; Accepted 11 June 2018; Published 25 July 2018

Academic Editor: Adina Negrea

Copyright (C) 2018 Xi Chen et al. This is an open access article distributed under the Creative Commons Attribution License, which permits unrestricted use, distribution, and reproduction in any medium, provided the original work is properly cited.

\begin{abstract}
Environmental effects of excessive amounts of atmospheric nitrogen $(\mathrm{N})$ deposition have raised a great deal of attention. In the present study, the characteristics of $\mathrm{N}$ deposition and its contribution to water eutrophication were investigated in the Taihu Basin. The results showed that the annual average total deposition $(\mathrm{TN})$, total wet deposition $\left(\mathrm{TN}_{\mathrm{W}}\right)$, and total dry deposition $\left(\mathrm{TN}_{\mathrm{D}}\right)$ rates were 6154,1142 , and $5012 \mathrm{~kg} \cdot \mathrm{km}^{-2}$, respectively. Moreover, seasonal fluctuations in $\mathrm{TN}, \mathrm{TN} \mathrm{W}_{\mathrm{W}}$, and $\mathrm{TN}_{\mathrm{D}}$ deposition were observed, with a higher $\mathrm{N}$ deposition rate occurring in spring and summer. Spatially, the distribution of TN and $\mathrm{TN}_{\mathrm{D}}$ deposition throughout the Taihu Basin was similar. However, the TN deposition rate declined gradually from the southeast to the northwest, while the $\mathrm{TN}_{\mathrm{W}}$ deposition rate increased. A significant positive correlation was also found between the TN deposition contents with rainfall $(R=0.803, P=0.01)$, rainfall frequency $(R=0.767, P<0.01)$, and rainfall intensity $(R=0.659, P<0.05)$. The TN deposition concentration was significantly negatively correlated with rainfall $(R=-0.999, P<0.01)$, rain frequency $(R=-0.805, P<0.01)$, and rainfall intensity $(R=-0.783, P<0.01)$. The riverine input of TN was estimated to be $112,500 \mathrm{t} \cdot \mathrm{N} \cdot \mathrm{a}^{-1}$, and the main $\mathrm{N}$ pollutants originated from domestic sewage (accounting for $48.88 \%$ ) and agriculture (accounting for $28.17 \%$ ). Livestock and aquaculture contributed $90 \%$ of the agricultural pollutants. Additionally, TN deposition contributed $14,400 \mathrm{t} \mathrm{N} \cdot \mathrm{a}^{-1}$ to the lake, which accounted for $12.36 \%$ of the annual riverine TN inputs. The TN deposition load already exceeds the eutrophication critical load in theory. Furthermore, the contribution of $\mathrm{N}$ deposition to the lake has been increasing in recent years, which may accelerate eutrophication of Taihu Lake.
\end{abstract}

\section{Introduction}

Nitrogen $(\mathrm{N})$ deposition mainly originates from the discharge of nitrogen oxides $\left(\mathrm{NO}_{x}\right)$, nitrate nitrogen $\left(\mathrm{NO}_{3}{ }^{-}-\mathrm{N}\right)$, ammonia nitrogen $\left(\mathrm{NH}_{3}\right)$, and ammonium nitrogen $\left(\mathrm{NH}_{4}{ }^{+}-\right.$ $\mathrm{N})$ from both anthropogenic and natural sources. Ultimately, these compounds return to the surface via wet and dry deposition $[1,2]$. Atmospheric $\mathrm{N}$ deposition represents an important source of reactive $\mathrm{N}$ to the ecosystems $[3,4]$.
However, excessive $\mathrm{N}$ inputs could cause adverse ecological effects, including soil acidification, plant biodiversity reduction, and eutrophication [5-7]. Many literature studies have shown that the concentration of $\mathrm{N}$ deposition in water $\mathrm{N}$ loads has increased [8-10], and the ecological effects of atmospheric $\mathrm{N}$ deposition have received a great deal of attention in recent years $[11,12]$. Many methods have been employed to collect $\mathrm{N}$ deposition, including ion-exchange resin, micrometeorological integral total $\mathrm{N}$ input, and 
minusing methods [13-16]. Due to the rapid population growth, industrialization, vehicle ownership, and fossil fuel combustion, the $\mathrm{NO}_{x}$ emissions in China have shown a marked increase of 2.8 times from 1980 to 2003 [17, 18]. It is also believed that both the excessive use of chemical $\mathrm{N}$ fertilizer and increasing amounts of human, aquaculture, and livestock excrement may have increased $\mathrm{NH}_{3}$ emissions [19]. The fertilizer production in China in 2010 brought out $37.10 \mathrm{Tg}$ of N. Among them, $75.74 \%$ was consumed by domestic agriculture, much more than the total world production and consumption. However, less than half of the $\mathrm{N}$ application was taken up by the crops [20]. The majority was discharged into the waterbody or the atmosphere by runoff and volatilization. The average total $\mathrm{NH}_{3}$ emissions in China is $15 \mathrm{Tg} \mathrm{N} \cdot \mathrm{a}^{-1}$, approximately $90 \%$ of which is contributed by agricultural activities [21, 22]. Rapid economic development has resulted in a significant increase in reactive $\mathrm{N}$ creation worldwide in recent years [19]. It is estimated that the total reactive $\mathrm{N}$ produced by anthropogenic activities ranged from $15 \mathrm{Tg}$ in 1860 to $165 \mathrm{Tg}$ in 1995, and global TN deposition is expected to reach $195 \mathrm{Tg}$ in 2050 [17]. In China, the total $\mathrm{NO}_{x}$ emission from anthropogenic activities increased from $8.40 \mathrm{Tg} \cdot \mathrm{N} \cdot \mathrm{a}^{-1}$ in 1990 to $11.30 \mathrm{Tg} \cdot \mathrm{N} \cdot \mathrm{a}^{-1}$ in 2000 , while the total $\mathrm{NH}_{3}$ emissions rose from $10.80 \mathrm{Tg} \cdot \mathrm{N} \cdot \mathrm{a}^{-1}$ to $13.60 \mathrm{Tg} \cdot \mathrm{N} \cdot \mathrm{a}^{-1}$ $[23,24]$. Western Europe, China, and India have had the highest $\mathrm{N}$ deposition in the world in recent years [25].

The Taihu watershed has played an important role in the water quantity regulation, industry, agriculture, and tourism. The lake water was under the oligotrophic status in the 1950s [26]. However, it underwent more aggravated eutrophication in the mid-1980s because of the rapid industrial and agricultural development and excessive population growth [27]. Large amounts of nutrients have been discharged into the Taihu Lake via river runoff and $\mathrm{N}$ deposition. As a result, the natural environment of Taihu Lake has already deteriorated significantly, and water eutrophication has become a serious problem $[10,27-29]$. As a result, many policies have been initiated to improve the water quality of Taihu Lake. Nevertheless, the Taihu Lake water quality has not improved remarkably. Many prior case studies have been conducted to determine the origins and forms of $\mathrm{N}$ entering the system [30-33]. From year 2002, a series of investigations for atmospheric $\mathrm{N}$ deposition in Taihu Lake have focused on more and more attention and the results were used for preliminary calculation of the contribution of $\mathrm{N}$ deposition to the lake $[9,10,28]$. However, studies of the temporal and spatial distribution of $\mathrm{N}$ deposition and the contribution to the water eutrophication of Taihu Lake need further focus. Therefore, the present study was conducted to (1) characterize the atmospheric $\mathrm{N}$ deposition, (2) make a unified calculation of $\mathrm{N}$ migration and transformation in the system, (3) calculate $\mathrm{N}$ loads from the inflowing rivers and explore the contribution of $\mathrm{N}$ deposition to the water eutrophication, and (4) provide a reference for economic development and environmental governance in the study area.

\section{Materials and Methods}

2.1. Study Area. The Taihu watershed $\left(29^{\circ} 55^{\prime} \sim 32^{\circ} 19^{\prime} \mathrm{N}\right.$, $118^{\circ} 50^{\prime} \sim 121^{\circ} 55^{\prime} \mathrm{E}$ ) is located in the lower Yangtze River Delta
(Figure 1). The watershed extends across Jiangsu Province (53\% of the watershed area), Zhejiang Province (33.40\%), Anhui Province (0.1\%), and Shanghai (13.50\%). Taihu Lake, the third largest freshwater lake in China, is a typical large shallow lake with an area of $2338 \mathrm{~km}^{2}$ and a mean depth of $1.90 \mathrm{~m}$. More than 200 streams flow radially into the lake. The Taihu watershed is characterized by a typical subtropical monsoon climate, with an annual mean temperature of $16^{\circ} \mathrm{C}$ and dominant soil types of yellow-brown soil, red soil, and paddy soil. The main crops in the region are wheat and rice. Excessive use of $\mathrm{N}$ fertilizer is common, particularly in regions with high population densities, and the average $\mathrm{N}$ fertilizer application rate is $570 \sim 600 \mathrm{~kg} \cdot \mathrm{ha}^{-1}$ in the ricewheat double cropping rotation system [31]. However, only $\sim 35 \%$ of fertilizer is absorbed in the season [21, 31]. The rest enters into the environment. For the livestock breeding, free-range chickens and ducks mode is dominant. Approximately $65 \%$ of the livestock manure in the region is disposed by the concentrated treatment, while $35 \%$ of the undisposed manure is discharged directly into the waterbody [21], resulting in excessive $\mathrm{N}$ levels in local aquatic systems [21, 31].

The Taihu watershed has undergone a very high degree of urbanization and became the most important comprehensive industrial base in China [34-37]. As of 2015, the population of the region was 68.27 million, and the GDP per capita in the lake basin was USD 1,325. These increased anthropogenic activities have increased the $\mathrm{N}$ deposition rate and aggravated eutrophication [26-39].

\subsection{Extraction N Deposition Data and Correlation Analysis.} The simulation atmospheric $\mathrm{N}$ deposition data (in 2015) were obtained through RAMS-CMAQ (Models 3, USA), and the horizontal resolution was $64 \mathrm{~km}$. The total wet deposition $\left(\mathrm{TN}_{\mathrm{w}}\right)$, total dry deposition $\left(\mathrm{TN}_{\mathrm{D}}\right)$, and total nitrogen (TN) rates, which included $\mathrm{NO}_{x}\left(\mathrm{NO}, \mathrm{NO}_{2}, \mathrm{NO}_{3}\right.$, $\mathrm{N}_{2} \mathrm{O}$, and $\mathrm{N}_{2} \mathrm{O}_{5}$ ), $\mathrm{NH}_{3}, \mathrm{NO}_{3}{ }^{-}-\mathrm{N}$, and $\mathrm{NH}_{4}{ }^{+}-\mathrm{N}$ were organized using the MATLAB 8.0 (The MathWorks Company, USA) software. All atmospheric $\mathrm{TN}_{\mathrm{W}}$ and $\mathrm{TN}_{\mathrm{D}}$ deposition rates were obtained using the Kriging interpolation and mask extraction tool of Spatial Analysis from ArcGIS 10.0 (ESRI, USA). Additionally, SPSS 18.0 (IBM, USA) was used to make a curve estimation between the concentration of $\mathrm{TN}_{\mathrm{W}}, \mathrm{NH}_{x}-\mathrm{N}$ (including $\mathrm{NH}_{4}{ }^{+}-\mathrm{N}$ and $\mathrm{NH}_{3}$ ), and $\mathrm{NO}_{3}{ }^{-}-\mathrm{N}$ deposition rate monthly and meteorological conditions. The concentration of wet $\mathrm{N}$ deposition had a power-type correlation with rainfall. The Pearson correlation method was used.

2.3. Calculation of $N$ Inputs. Calculation of the $\mathrm{N}$ inputs into a river from different pollutant sources is very complicated, and considerable uncertainty in the results exists because of the fluctuating emission coefficients in different regions [29, 30, 40]. Accordingly, determination of the emission coefficient is essential for calculation of the $\mathrm{N}$ inputs into the waterbody. In the present study, we calculated the main pollutant source of agricultural (chemical fertilizer, livestock, and aquaculture), domestic 


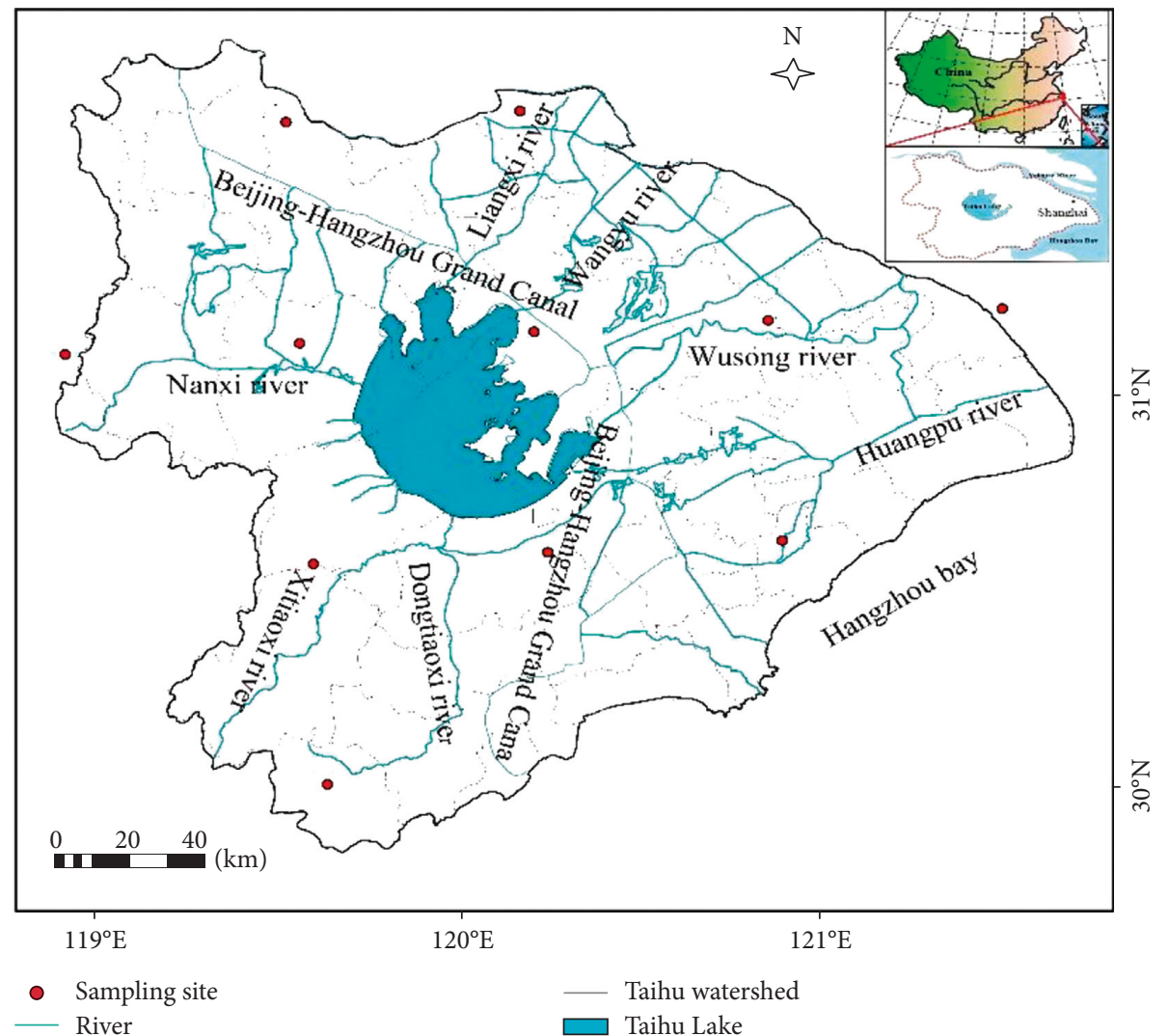

Figure 1: Location and administrative divisions of the Taihu watershed.

TABLE 1: Coefficients of various pollutants produced and discharged into rivers.

\begin{tabular}{lccccc}
\hline & $\begin{array}{c}\text { Industrial effluents } \\
{[41]}\end{array}$ & $\begin{array}{c}\text { Urban sewage } \\
{[42,43]}\end{array}$ & $\begin{array}{c}\text { Rural-domestic sewage } \\
{[44]}\end{array}$ & $\begin{array}{c}\text { Runoff fertilizer } \\
{[38]}\end{array}$ & $\begin{array}{c}\text { Aquaculture } \\
{[28,45]}\end{array}$ \\
\hline $\begin{array}{l}\text { Emission coefficient } \\
\begin{array}{l}\text { Coefficient into } \\
\text { water }\end{array}\end{array}$ & - & $2.92 \mathrm{~kg} \cdot \mathrm{N} \cdot \mathrm{a}^{-1} \cdot \mathrm{capita}^{-1}$ & $2.19 \mathrm{~kg} \cdot \mathrm{N} \cdot \mathrm{a}^{-1} \cdot \mathrm{capita}^{-1}$ & - & $1800 \mathrm{~kg} \cdot \mathrm{N} \cdot(\mathrm{ha} \cdot \mathrm{a})^{-1}$ \\
\hline
\end{tabular}

TAble 2: Different N produced and loss coefficients by livestock.

\begin{tabular}{lcccccc}
\hline & Pig manure & Pig urine & Cattle manure [42] & Cattle urine [42] & Sheep [29] Chicken [29, 43] \\
& {$[44]$} & {$[44]$} & & & \\
\hline Emission coefficient $\left(\mathrm{kg} \cdot \mathrm{N} \cdot \mathrm{a}^{-1} \cdot \mathrm{capita}^{-1}\right)$ & 2.34 & 2.17 & 31.90 & 29.20 & 2.28 & 0.28 \\
Coefficient into water & 1.08 & 50.00 & 5.60 & 50.00 & 10.00 & 7.80 \\
\hline
\end{tabular}

sewage (urban-domestic sewage and rural-domestic sewage), and industrial effluents (Table 1) by the following equation:

$$
N_{\mathrm{T}}=N_{\mathrm{A}} \cdot f_{\mathrm{A}}+N_{\mathrm{B}} \cdot f_{\mathrm{B}}+N_{\mathrm{C}} \cdot f_{\mathrm{C}}+N_{\mathrm{E}} \cdot f_{\mathrm{E}},
$$

where $N_{\mathrm{T}}\left(\mathrm{t} \cdot \mathrm{N} \cdot \mathrm{a}^{-1}\right)$ is the total $\mathrm{N}$ discharged to surface water, $N_{i}(i=\mathrm{A}, \mathrm{B}, \mathrm{C}$, and $\mathrm{E})$ is the emission coefficient, and $f_{i}(i=\mathrm{A}, \mathrm{B}, \mathrm{C}$, and $\mathrm{E})$ is the coefficient of pollutants into the waterbody [41], where A represents industrial effluent [42], $\mathrm{B}$ is urban-domestic sewage [43,44], C is rural-domestic sewage $[44,45]$, and $\mathrm{E}$ is agricultural pollution $[29,46]$, and the emission coefficient of livestock was determined as shown in Table 2.

\section{Results and Discussion}

3.1. Chemical Morphological Characteristics of $N$ Deposition. The deposition rates of TN, $\mathrm{TN}_{\mathrm{W}}, \mathrm{TN}_{\mathrm{D}}, \mathrm{NO}_{3}{ }^{-} \mathrm{-N}$, and $\mathrm{NH}_{4}{ }^{+}-$ $\mathrm{N}$ were $6514,1142,5012,878$, and $1207 \mathrm{~kg} \cdot \mathrm{km}^{-2} \cdot \mathrm{a}^{-1}$, respectively (Table 3 ). The TN deposition rate was higher than that observed in previous studies [10, 19,47]. The main $\mathrm{N}$ deposition is dry deposition, which accounted for $81.40 \%$. Additionally, the $\mathrm{NH}_{4}{ }^{+}-\mathrm{N} / \mathrm{NO}_{3}{ }^{-}-\mathrm{N}$ was $1.4: 1$, indicating that the pollution resources may originate from the agricultural activities, as well as rural and urban sewage [48]. Because of the inadequate sewage treatment system, as well as the high fertilizer application coupled with low absorption, many $\mathrm{N}$ nutrients were emitted into the atmosphere [21, 31]. 
TABle 3: Monthly $\mathrm{N}$ deposition rate around the Taihu watershed $\left(\mathrm{kg} \cdot \mathrm{km}^{-2} \cdot \mathrm{a}^{-1}\right)$.

\begin{tabular}{|c|c|c|c|c|c|c|c|c|c|c|c|c|c|}
\hline \multirow{2}{*}{ Deposition } & \multicolumn{12}{|c|}{ Month } & \multirow{2}{*}{ Tota } \\
\hline & Jan & Feb & Mar & Apr & May & Jun & Jul & Aug & Sep & Oct & Nov & Dec & \\
\hline $\mathrm{TN}$ & 321 & 291 & 304 & 747 & 840 & 918 & 612 & 652 & 505 & 310 & 459 & 197 & 6154 \\
\hline $\mathrm{NH}_{4}{ }^{+}-\mathrm{N}$ & 46 & 31 & 55 & 129 & 159 & 248 & 132 & 114 & 78 & 55 & 103 & 59 & 1207 \\
\hline $\mathrm{NO}_{3}{ }^{-}-\mathrm{N}$ & 20 & 39 & 24 & 69 & 82 & 170 & 101 & 194 & 69 & 19 & 72 & 19 & 878 \\
\hline
\end{tabular}

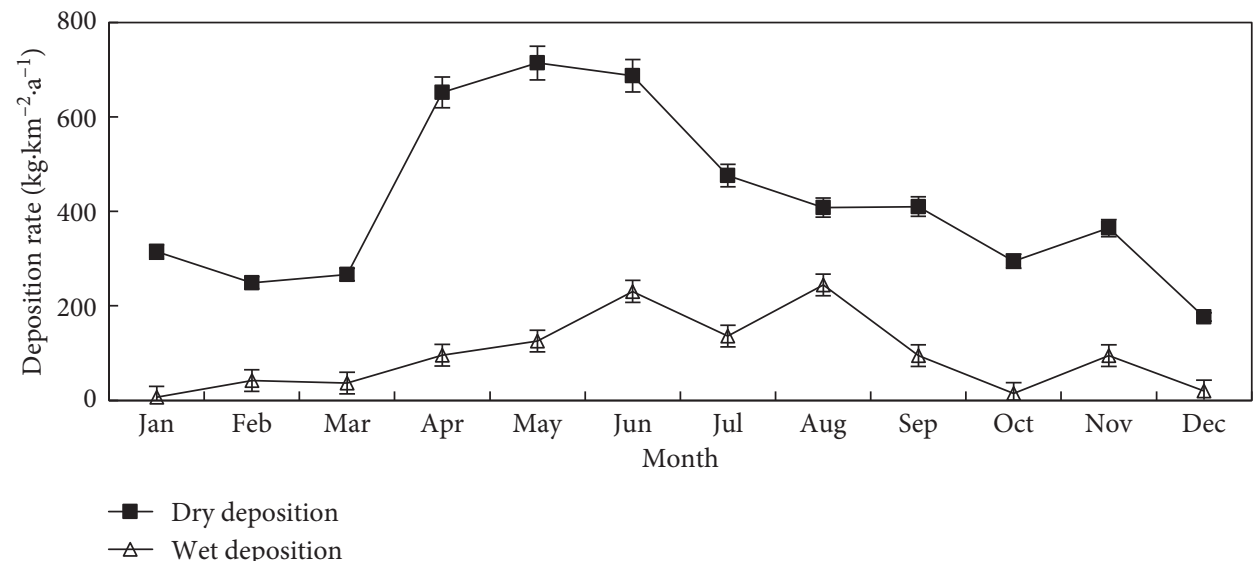

Figure 2: Seasonal variations in $\mathrm{N}$ deposition flux around the Taihu watershed.

3.2. Spatial and Temporal Distribution Characteristics of $N$ Deposition. The $\mathrm{TN}, \mathrm{TN}_{\mathrm{D}}$, and $\mathrm{TN}_{\mathrm{W}}$ deposition rates showed seasonal variations in 2015 (Figure 2). The $\mathrm{TN}_{\mathrm{W}}$ deposition rate was higher during summer than winter because an El Niño phenomenon occurred in 2015. Cyanobacteria usually grow rapidly in summer. At this time, the high $\mathrm{N}$ deposition rate may promote cyanobacterial blooms in Taihu Lake. The wet $\mathrm{N}$ deposition rate in July was lower than in June, which was affected by changes in rainfall. However, the continuous heavy rainfall in late June diluted the wet $\mathrm{N}$ deposition concentrations in the atmosphere. This phenomenon, coupled with the low rainfall in July (due to the basin being dominated by a subtropical high), caused the wet $\mathrm{N}$ deposition rate to decrease rapidly. The high rainfall in August and fertilizer application in the paddy field then led to a remarkable increase in the wet $\mathrm{N}$ deposition rate.

The $\mathrm{TN}_{\mathrm{D}}$ deposition rate increased rapidly during spring, while it decreased in summer (Figure 2). The $\mathrm{NH}_{3}$ volatilizing from the fertilizer application is emitted into the atmosphere and then deposited back to the ground after 15 days. Application of fertilizer and pesticides may enhance $\mathrm{N}$ deposition in spring. Moreover, unstable atmospheric conditions will increase the deposition rate of particulate matter [49]. Some literature studies have shown that the deposition of $\mathrm{NO}_{x}$ and $\mathrm{NO}_{3}{ }^{-}-\mathrm{N}$ are both positively correlated with illumination intensity. Consequently, the dry deposition rate may increase due to the rising temperatures in spring. After fertilizer application to oilseed rape and wheat, the amount of dry $\mathrm{N}$ deposition increased significantly in November.

The rates of $\mathrm{TN}_{\mathrm{W}}$ and $\mathrm{TN}_{\mathrm{D}}$ deposition both showed significant spatial distribution in 2015 (Figure 3). Specifically, the $\mathrm{TN}_{\mathrm{W}}$ deposition rate decreased gradually from northwest to southeast, while the $\mathrm{TN}_{\mathrm{D}}$ deposition rate increased. The wet deposition rates were highest $\left(1640 \mathrm{~kg} \cdot \mathrm{km}^{-2} \cdot \mathrm{a}^{-1}\right)$ in Changzhou and Zhenjiang, which are in the northwest of the Taihu Lake Basin. Low levels of deposition $\left(500 \sim 770 \mathrm{~kg} \cdot \mathrm{km}^{-2} \cdot \mathrm{a}^{-1} \cdot \mathrm{TN}_{\mathrm{W}}\right)$ were observed in Shanghai. The precipitation in the northern Taihu Lake Basin was higher than that in the south in 2015, with the largest precipitation of $1186.7 \mathrm{~mm}$ occurring in the $\mathrm{Wu}-\mathrm{Cheng}-\mathrm{Xi}-\mathrm{Yu}$ area. The higher rainfall which resulted in more $\mathrm{N}$ deposition in this area may be the reason.

The low levels of precipitation in Shanghai resulted in most of the particulate matter returning to the surface via dry deposition. Indeed, the highest dry deposition rate of $10,870 \mathrm{~kg} \cdot \mathrm{km}^{-2} \cdot \mathrm{a}^{-1}$ was observed in Shanghai. Moreover, $\mathrm{N}$ deposition formed a high-value band in the cities of Shanghai, Suzhou, Wuxi, and Changzhou because of the higher levels of the industrialization and urbanization. The increased $\mathrm{N}$ nutrients accumulated through the discharges from the urban sewage and fossil fuel, especially from vehicle exhaust. Suzhou, which is located on the west of Taihu Lake, has an open terrain and high amount of green area, resulting in lower pollution, and therefore lower $\mathrm{N}$ deposition, than other cities.

3.3. Comparisons of $N$ Deposition Values. Monitoring of the deposition rates of $\mathrm{TN}_{\mathrm{W}}, \mathrm{NH}_{4}{ }^{+}-\mathrm{N}$, and $\mathrm{NO}_{3}{ }^{-}-\mathrm{N}$ revealed values of 1647,986 , and $661 \mathrm{~kg} \cdot \mathrm{km}^{-2} \cdot \mathrm{a}^{-1}$, respectively, in Nanjing from July 2015 to June 2016 (Figure 4). The simulated deposition rates of $\mathrm{TN}_{\mathrm{W}}, \mathrm{NH}_{4}{ }^{+}-\mathrm{N}$, and $\mathrm{NO}_{3}{ }^{-}-\mathrm{N}$ were 1653 , 508 , and $1144 \mathrm{~kg} \cdot \mathrm{km}^{-2} \cdot \mathrm{a}^{-1}$, respectively. Both the monitored and simulated values showed significant seasonal variations in spring and summer. An obvious decrease in the monitored $\mathrm{N}$ 


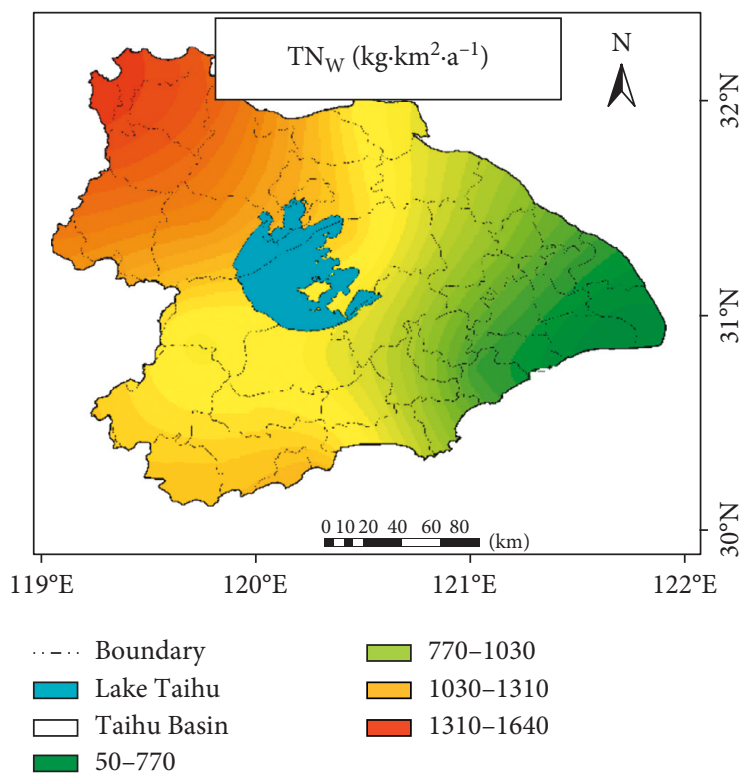

(a)

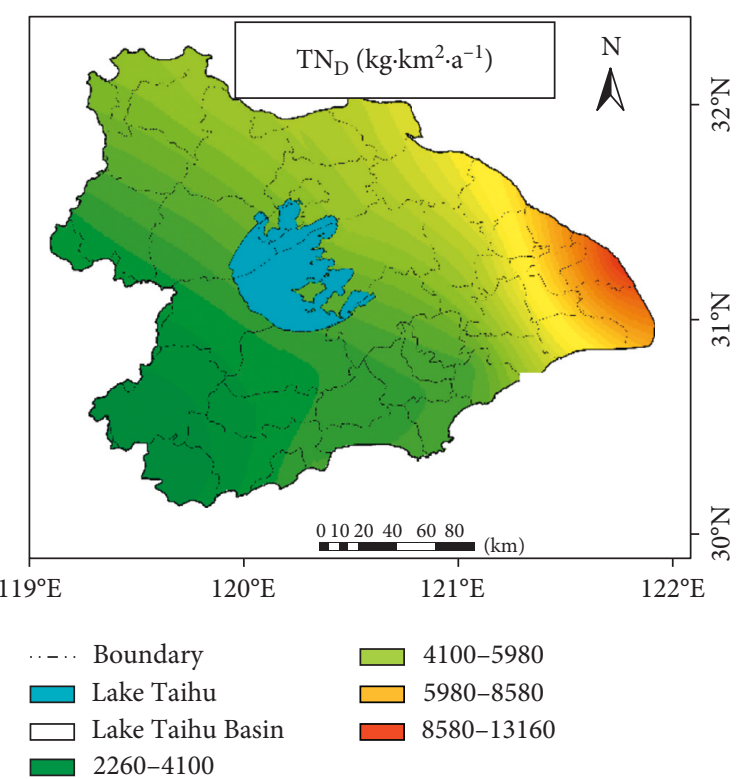

(b)

Figure 3: Spatial variations in $\mathrm{N}$ deposition $\left(\mathrm{kg} \cdot \mathrm{km}^{2} \cdot \mathrm{a}^{-1}\right)$ in the Taihu watershed.

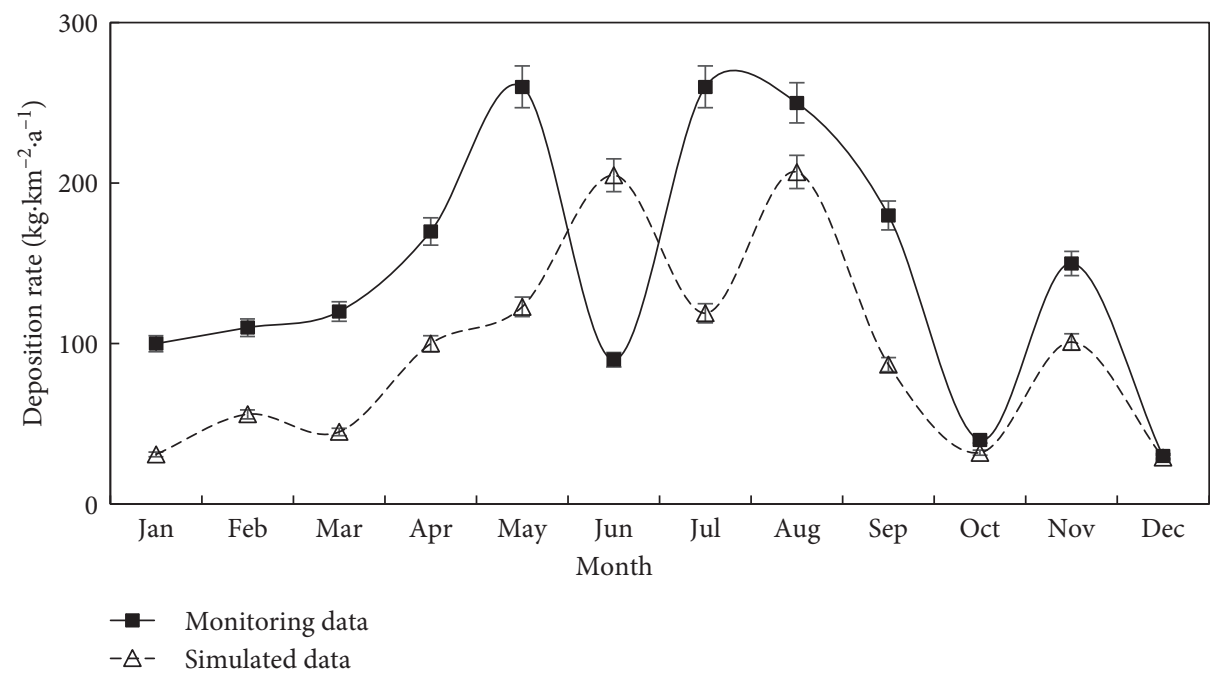

FIGURE 4: Monthly TN deposition $\left(\mathrm{kg} \cdot \mathrm{N} \cdot \mathrm{km}^{2} \cdot \mathrm{a}^{-1}\right)$ in Nanjing and the simulated value for the Taihu watershed.

deposition rate in June 2016 was observed. Less precipitation at this time may be the reason. However, the rainy season began in July. In the meantime, the $\mathrm{N}$ deposition rate increased remarkably. Overall, there was good consistency between the monitored and simulated values.

Atmospheric total wet inorganic nitrogen $\left(\mathrm{TIN}_{\mathrm{w}}\right)$ deposition rates in the Taihu watershed were compared with those for other areas in China (Figure 5). The $\operatorname{TIN}_{\mathrm{w}}$ in the Taihu watershed was higher than in other regions of China from 2001 to 2015. Specifically, the $\operatorname{TIN}_{\mathrm{w}}$ deposition rate in the Taihu watershed increased before 2011 and then decreased obviously. The mean annual $\mathrm{TIN}_{\mathrm{w}}$ deposition rates in the Taihu watershed, North China Plain, Pearl River Delta, and Western China were 2736, 2352, 2267, and $446 \mathrm{~kg} \cdot \mathrm{km}^{-2}$ from 2001 to 2015 , respectively. However, if the dry deposition rate was considered, the North China Plain had the highest TN deposition rate because the dry deposition rate is higher in northern than in southern China. Consequently, the mean annual TN deposition rate would reach from 3908 to $4560 \mathrm{~kg} \cdot \mathrm{km}^{-2}$ in the Taihu watershed. Obviously, the TN deposition load already exceeds the theoretical critical eutrophication load of $491 \mathrm{~kg} \cdot \mathrm{km}^{-2} \cdot \mathrm{a}^{-1}$ [9].

3.4. Influence of Meteorological Conditions on N Deposition. Results of the Pearson correlation analysis showed that meteorological conditions were significantly correlated with $\mathrm{TN}_{\mathrm{w}}$ deposition rate (Table 4 and Figure 6). Moreover, a significantly negative correlation was found between the concentration of $\mathrm{TN}$ deposition and rainfall $(Y=$ 


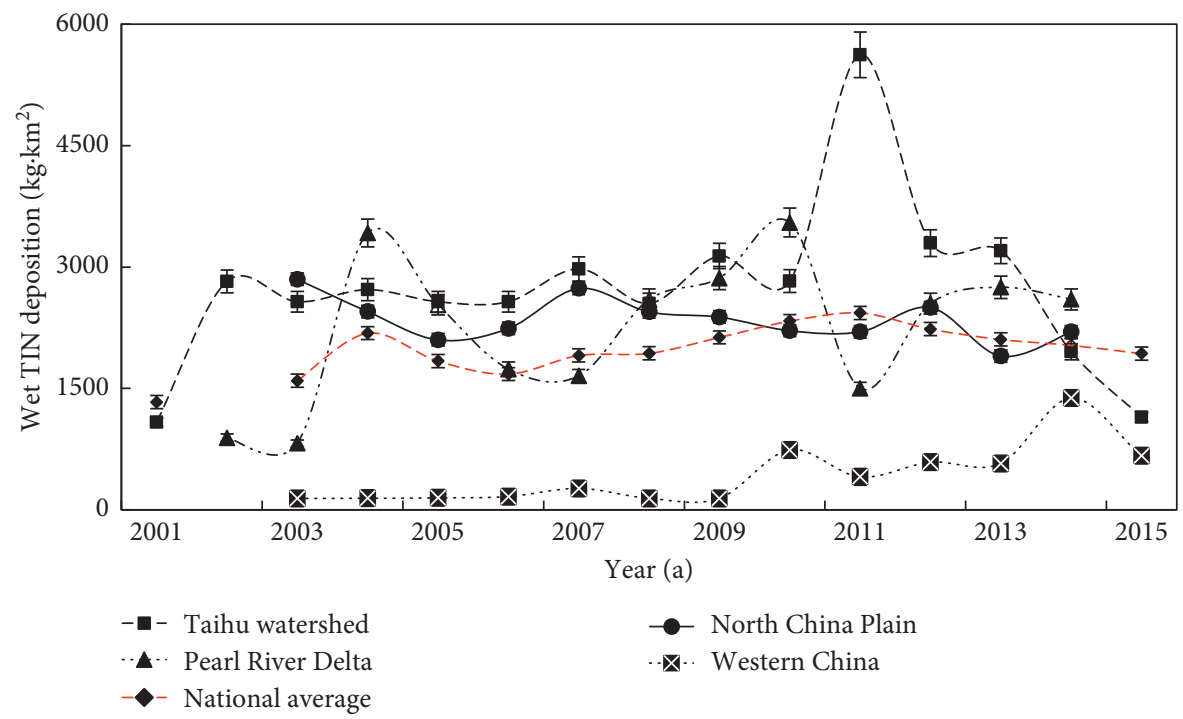

Figure 5: Comparisons of atmospheric $\operatorname{TIN}_{\mathrm{w}}$ deposition rate listed with other domestic areas.

TABle 4: Correlation $(R)$ between wet $\mathrm{N}$ deposition and meteorological conditions.

\begin{tabular}{lccccc}
\hline & Rainfall & Frequency & Intensity & N deposition & Concentration \\
\hline Rainfall & 1 & - & - & - & - \\
Frequency & $0.646^{*}$ & 1 & - & - & - \\
Intensity & $0.933^{* *}$ & 0.343 & 1 & 1 & - \\
N deposition & $0.803^{* *}$ & $0.767^{* *}$ & $0.659^{*}$ & $-0.847^{* *}$ & - \\
Concentration & $-0.999^{* *}$ & $-0.805^{* *}$ & $-0.783^{* *}$ & - \\
\hline
\end{tabular}

Values are given with their level of significance: ${ }^{* *} p<0.01 ;{ }^{*} p<0.05$.

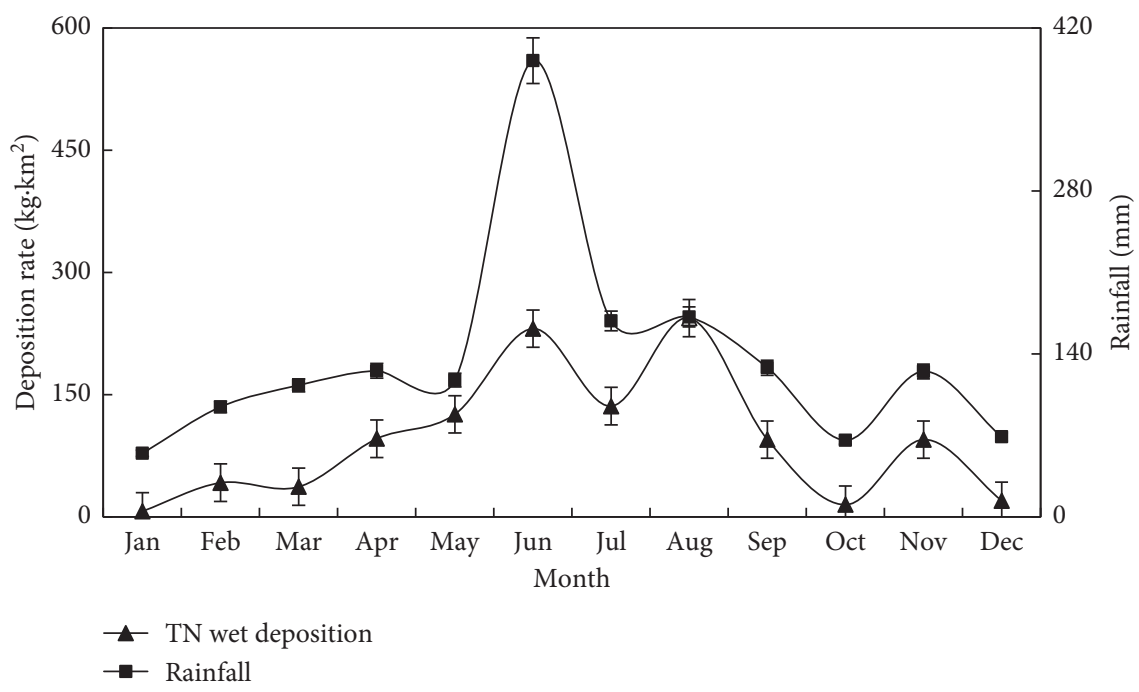

Figure 6: Monthly rainfall and $\mathrm{TN}_{\mathrm{w}}$ deposition.

$\left.189.268 X^{-0.997}, R=-0.999, P<0.01\right)$, rainfall frequency $(R=$ $-0.783, P<0.01)$, and rain intensity $(R=-0.783, P<0.01)$. However, it was significantly positively correlated with TN deposition. Under the same precipitation scale, the $\mathrm{N}$ concentration of rain may gradually decrease. The negative correlation indicates that precipitation can remove $\mathrm{N}$ nutrients from the atmosphere and that light rain results in greater removal than heavy rain. The positive correlation between precipitation and $\mathrm{N}$ deposition rate explains the cumulative effect of $\mathrm{N}$ nutrients in water bodies after rainfall, as well as the dilution effect of heavy rain.

3.5. Influence of $\mathrm{NH}_{3}$ from Agriculture on $\mathrm{N}$ Deposition. Agricultural activities may be the major sources of $\mathrm{NH}_{3}$ emissions, especially from livestock and fertilizer volatilization. Changshu, which has a good agricultural base in theTaihu watershed, was investigated in this study. A remarkable 


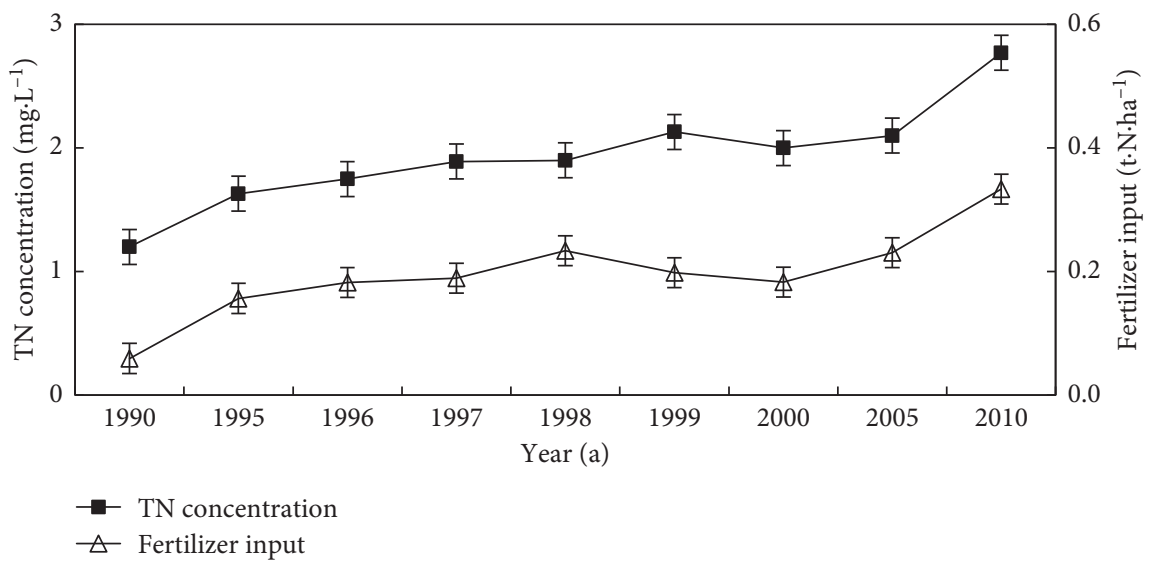

FIgURE 7: Chemical fertilizer input and TN content of water in Changshu from 1990 to 2010.

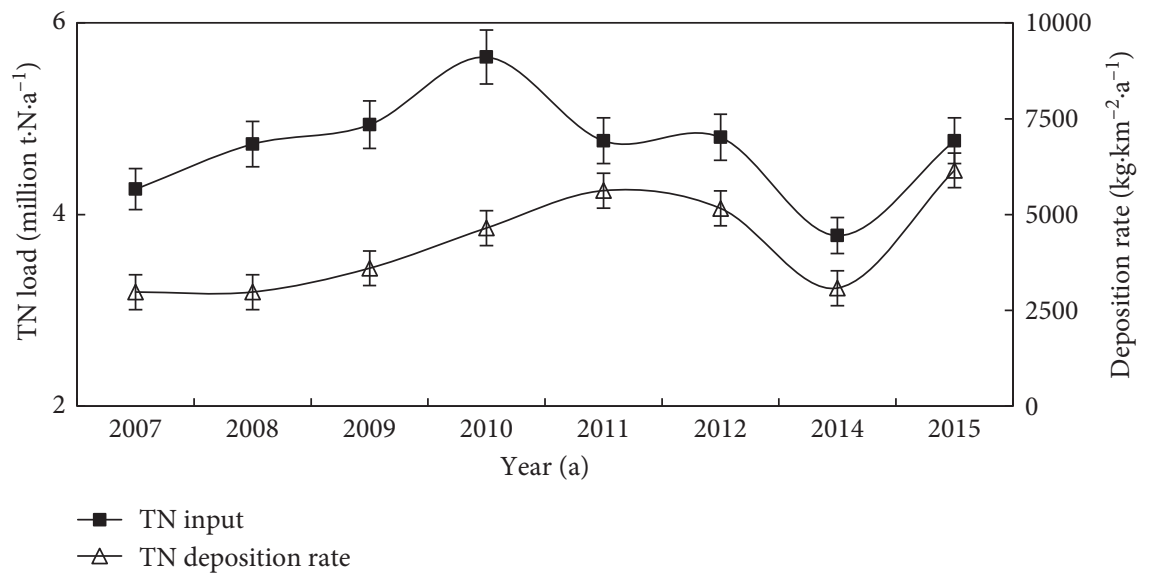

Figure 8: TN input into the lake and TN deposition rate in Taihu watershed from 2007 to 2015.

correlation between $\mathrm{TN}$ loads of water and $\mathrm{N}$ fertilizer applied per hectare was observed (Figure 7). Fertilizer is applied to rice paddies, wheat fields, and oilseed rape fields in March, July, and November. At that time, the wet $\mathrm{N}$ deposition rate increased rapidly, demonstrating that ammonia from farmland fertilizer made a significant contribution to $\mathrm{N}$ deposition. With the excessive fertilizer application and low absorptivity in this area, the concentration of TN in water bodies has increased in recent years. The mean $\mathrm{NH}_{3}$ deposition rate was found to be $688 \mathrm{~kg} \cdot \mathrm{ha}^{-1}$, accounting for $56.80 \%$ of $\mathrm{NH}_{3}{ }^{+}-\mathrm{N}$ from the simulation date. Consequently, the volatilization of $\mathrm{NH}_{3}$ from fertilizer concentration to $\mathrm{N}$ deposition cannot be ignored.

The typical characteristics of livestock and aquaculture are free-ranging in or near the water bodies in this area. About $35 \%$ of the manure was discharged into the river directly from undisposed manure [21, 31]. The gross value of production of aquaculture increased from USD 0.87 billion in 2000 to USD 2.13 billion in 2015, while the gross value of livestock production increased from USD 0.5 billion to USD 1 billion. Increasing amounts of $\mathrm{N}$ are discharged into aquatic systems and the atmosphere under the imperfect excrement disposal system. If effective measures are not taken, $\mathrm{NH}_{3}$ volatilized from agricultural systems will continue to increase because of the rapid development of livestock, aquaculture, and excessive fertilizer application.

3.6. Estimated Contribution of N Deposition to $N$ Loads of Water in the Taihu Watershed. Based on equation (1), the annual riverine input of TN was estimated to be $112,500 \mathrm{t} \mathrm{N} \cdot \mathrm{a}^{-1}$. The main $\mathrm{N}$ pollutants originated from domestic sewage (48.88\%) and agriculture (28.17\%). Among the agricultural pollutants, livestock and aquaculture contributed $90.00 \%$. However, many studies have shown that the heavy $\mathrm{N}$ load in Taihu Lake originated from agricultural activities. In the present study, the $\mathrm{TN}$ deposition load into the lake was calculated based on an area of $2338 \mathrm{~km}^{2}$ and an annual TN deposition load of $14,400 \mathrm{t} \mathrm{N} \cdot \mathrm{a}^{-1}$. The annual TN deposition accounted for $12.36 \%$ of the annual riverine input of TN.

When compared to the case studies conducted from 2007 to $2015[9,10,28,50-52]$, the contribution of $\mathrm{N}$ deposition to Taihu Lake showed an increasing trend (Figure 8). The eutrophication critical load of atmospheric $\mathrm{N}$ deposition, which is the minimal amount of $\mathrm{N}$ required to stimulate eutrophication, is lower than $658 \mathrm{~kg} \cdot \mathrm{km}^{-2} \cdot \mathrm{a}^{-1}$ for Taihu Lake [53]. Additionally, the allowable TN load in the Taihu Lake ecosystem was estimated to be only $491 \mathrm{~kg} \cdot \mathrm{km}^{-2} \cdot \mathrm{a}^{-1}$ 
[9], while the TN deposition rate was found to be $6514 \mathrm{~kg} \cdot \mathrm{km}^{-2} \cdot \mathrm{a}^{-1}$ in the present study. Obviously, the TN deposition load already exceeds the eutrophication critical load in theory. Accordingly, this phenomenon may accelerate the eutrophication process of Taihu Lake. Overall, our results indicate that the contribution of TN deposition to water $\mathrm{N}$ load cannot be ignored when the pollution sources are considered.

\section{Conclusions}

To better understand the spatial-temporal distribution characteristics of $\mathrm{N}$ deposition and its estimated contributions to water eutrophication, the $\mathrm{N}$ deposition in the Taihu watershed was investigated. The results revealed the following:

(1) Deposition rates of TN, wet deposition, dry deposition, $\mathrm{NO}_{3}{ }^{-}-\mathrm{N}$, and $\mathrm{NH}_{4}{ }^{+}-\mathrm{N}$ were 6514,1142 , 5012,878 , and $1207 \mathrm{~kg} \cdot \mathrm{km}^{-2} \cdot \mathrm{a}^{-1}$, respectively.

(2) The $\mathrm{TN}, \mathrm{TN}_{\mathrm{W}}$, and $\mathrm{TN}_{\mathrm{D}}$ deposition had significant temporal and spatial distribution features. Seasonally, both deposition rates were higher in spring and summer. Spatially, the $\mathrm{TN}_{\mathrm{W}}$ deposition rate decreased from northwest to southeast while the $\mathrm{TN}_{\mathrm{D}}$ deposition rate increased.

(3) Correlation analysis showed that rainfall was significantly correlated with $\mathrm{N}$ deposition rate. Rain could clean the atmosphere and that light rain did so more effectively than heavy rain.

(4) The TN deposition contributed to the Taihu lake was $14,400 \mathrm{t} \mathrm{N} \cdot \mathrm{a}^{-1}, 12.36 \%$ of the total annual $\mathrm{N}$ input via inflow rivers. The main $\mathrm{N}$ pollutants originated from urban domestic sewage and agriculture, especially fertilizer and livestock.

\section{Data Availability}

The data used to support the findings of this study are available from the corresponding author upon request.

\section{Conflicts of Interest}

The authors declare that there are no conflicts of interest regarding the publication of this paper.

\section{Acknowledgments}

This work was supported by the "973" Project of the Ministry of Science and Technology of China (Grant no. 2014CB953801) and the National Natural Science Foundation of China (Grant no. 41673107). The authors thank the Changshu AgroEcosystem Experimental Station, Chinese Academy of Sciences, for providing statistical data assistance.

\section{References}

[1] Y. H. Zhao, L. Zhang, Y. F. Chen et al., "Atmospheric nitrogen deposition to China: a model analysis on nitrogen budget and critical load exceedance," Atmospheric Environment, vol. 153, pp. 32-40, 2017.

[2] K. M. Russell, J. N. Galloway, S. A. Macko, J. L. Moody, and J. R. Scudlark, "Sources of nitrogen in wet deposition to the Chesapeake-Bay region," Atmospheric Environment, vol. 32, no. 14, pp. 3923-3927, 1998.

[3] J. N. Galloway, F. J. Dentener, D. G. Capone et al., "Nitrogen cycle: past, present and future," Biogeochemistry, vol. 70, no. 2, pp. 153-226, 2004.

[4] D. Fowler, M. Coyle, U. Skiba et al., "The global nitrogen cycle in the twenty-first century," Philosophical Transactions of the Royal Society B: Biological Sciences, vol. 368, no. 1621, article 20130164, 2013.

[5] A. F. Bouwman, D. P. Van Vuuren, R. G. Derwent, and M. Posch, "A global analysis of acidification and eutrophication of terrestrial ecosystems," Water, Air, and Soil Pollution, vol. 141, no. 1-4, pp. 349-382, 2002.

[6] W. D. Bowman, C. C. Cleveland, L. Halada, J. Hresko, and J. S. Baron, "Negative impact of nitrogen deposition on soil buffering capacity," Nature Geoscience, vol. 1, no. 11, pp. 767-770, 2008.

[7] C. J. Stevens, N. B. Dise, J. O. Mountford, and D. J. Gowing, "Impact of nitrogen deposition on the species richness of grasslands," Science, vol. 303, no. 5665, pp. 1876-1879, 2004.

[8] E. W. Boyer, C. L. Goodale, and N. A. Jaworks, "Anthropogenic nitrogen sources and relationship to riverine nitrogen export in the northeastern USA," Biogeochemistry, vol. 57, no. 1, pp. 137-169, 2002.

[9] S. J. Zhai, L. Y. Yang, and W. P. Hu, "Observations of atmospheric nitrogen and phosphorus deposition during the period of algal bloom formation in northern lake Taihu, China," Environment Management, vol. 44, no. 3, pp. 542551, 2009.

[10] H. Yu, L. L. Zhang, and S. W. Yan, "Atmospheric wet deposition characteristics of nitrogen and phosphorus nutrients in Taihu Lake and contributions to the lake," Research of Environmental Sciences, vol. 24, no. 11, pp. 1210-1219, 2011.

[11] P. M. Vitousek, J. D. Aber, and R. W. Howarth, "Human alteration of the global nitrogen cycle: sources and consequences," Ecological Applications, vol. 7, no. 3, pp. 737-750, 1997.

[12] W. Liu, X. Wang, and Y. Fan, "A review of atmospheric nitrogen deposition and its estimated contributions to nitrogen input of waters," Environmental Pollution and Control, vol. 36, no. 5, pp. 88-101, 2014.

[13] C. E. He, X. J. Liu, A. Fangmeier, and F. Zhang, "Quantifying the total airborne nitrogen input into agro-ecosystems in the north China plain," Agriculture, Ecosystems and Environment, vol. 121, no. 4, pp. 395-400, 2007.

[14] M. E. Fenn, M. A. Poth, and M. J. Arbaugh, "A through fall collection method using mixed bed ion exchange resin columns," Scientific World Journal, vol. 2, pp. 122-130, 2014.

[15] D. H. Guo and Y. Y. Zhang, "The study of atmospheric dry depositions buffer action for precipitation," Journal of Hubei University: Natural Science, vol. 1, pp. 96-100, 1987.

[16] D. Fowler, M. Coyle, C. Flechard et al., "Advances in micrometeorological methods for the measurement and interpretation of gas and particle nitrogen fluxes," Plant and Soil, vol. 228, no. 1, pp. 117-129, 2011.

[17] D. G. Streets, T. C. Bond, G. R. Carmichael et al., "An inventory of gaseous and primary aerosol emissions in Asia in the year 2000," Journal of Geophysical Research, vol. 108, no. 21, pp. 1-23, 2003. 
[18] T. Ohara, H. Akimoto, J. Kurokawa et al., "An Asian emission inventory of anthropogenic emission sources for the period 1980-2020," Atmospheric Chemistry and Physics Discussion, vol. 7, no. 16, pp. 6843-6902, 2007.

[19] X. Zhao, X. Y. Yan, and Z. Q. Xiong, "Spatial and temporal variation of inorganic nitrogen wet deposition to the Yangzi River Delta Region, China," Water, Air, and Soil Pollution, vol. 203, no. 1-4, pp. 277-298, 2009.

[20] F. S. Zhang, J. Q. Wang, W. F. Zhang et al., "Nutrient use efficiencies of major cereal crops in China and measures for improvement," Acta Pedologica Sinica, vol. 45, no. 5, pp. 915-924, 2008, in Chinese.

[21] X. T. Ju, B. J. Gu, and Z. C. Cai, "Suggestions to mitigate haze by reducing agricultural ammonia emission," Science and Technology Review, vol. 35, no. 13, pp. 11-12, 2017.

[22] B. $\mathrm{Gu}, \mathrm{X} . \mathrm{Ju}$, and J. Chang, "Integrated reactive nitrogen budgets and future trends in China," Proceedings of the National Academy of Sciences, vol. 112, no. 28, pp. 8792-8797, 2015.

[23] W. Wang, W. Zhang, and S. Hong, "Geographical distribution of $\mathrm{SO}_{2}$ and $\mathrm{NO}_{\mathrm{x}}$ emission intensities and trends in China," China Environmental Science, vol. 16, pp. 161-167, 1996.

[24] Q. R. Sun and M. R. Wang, "Ammonia emission and concentration in the atmosphere over China," Chinese Journal of Atmospheric Sciences, vol. 21, no. 5, pp. 590-598, 1997.

[25] A. R. Townsend, B. H. Braswell, E. A. Holland, and J. E. Penner, "Spatial and temporal patterns in terrestrial carbon storage due to deposition of fossil fuel nitrogen," Ecological Applications, vol. 6, no. 3, pp. 806-814, 1996.

[26] Y. B. Chang, "Major environmental changes since 1950 and the onset of accelerated eutrophication in Taihu Lake, China," Acta Palaeontologica Sinica, vol. 35, no. 2, pp. 155-174, 1995, in Chinese.

[27] X. L. Dai, P. Q. Ye, L. Qian, and T. Song, "Changes in nitrogen and phosphorus concentrations in Lake Taihu, 19852015," Journal of Lake Sciences, vol. 28, no. 5, pp. 935-943, 2016.

[28] Y. Z. Song, B. Q. Qin, L. Y. Yang, and W. P. Hu, "Primary estimation of atmospheric wet deposition of nitrogen to aquatic ecosystem of Lake Taihu," Journal of Lake Sciences, vol. 17, no. 3, pp. 226-230, 2005.

[29] C. M. Li, S. G. Zhang, and W. P. Yao, "Study on agricultural non-point source pollution load of Taihu Lake Basin in Suzhou," Research of Soil and Water Conservation, vol. 23, no. 3, pp. 354-359, 2016.

[30] Y. P. Huang, Water Environment and its Pollution Control in Taihu Lake, Beijing Science Press, Beijing, China, 2001.

[31] H. J. Zhang and F. Chen, "Non-point pollution statistics and control measures in Taihu Basin," Water Resources Protection, vol. 26, no. 3, pp. 87-90, 2010.

[32] X. H. Wan and H. Q. Wang, "Analysis of agricultural surface source pollution and control measures in Lake Taihu basin of Jiangsu province," Agro-Environment and Development, vol. 25, no. 3, pp. 69-71, 2008.

[33] Y. Y. Shen, D. L. Hu, and Q. L. Jiang, "Characteristic of nitrogen and phosphorus load in the past three decades in the northwest of Lake Taihu basin based on the SWAT model," Resources and Environment in the Yangtze Basin, vol. 26, no. 6, pp. 902-914, 2017.

[34] Jiangsu Province Statistics Bureau, Statistical Yearbook of Jiangsu Province from 2000 to 2016, Jiangsu province Statistics Bureau, Jiangsu, China, 2016.
[35] Anhui Province Statistics Bureau, Statistical Yearbook of Anhui Province from 2000 to 2016, Anhui Province Statistics Bureau, Anhui, China, 2016.

[36] Zhejiang Province Statistics Bureau, Statistical Yearbook of Zhejiang Province from 2000 to 2016, Zhejiang Province Statistics Bureau, Zhejiang, China, 2016.

[37] Shanghai Statistics Bureau, Statistical Yearbook of Shanghai from 2000 to 2016, Shanghai Statistics Bureau, Shanghai, China, 2016.

[38] Y. L. Wu, H. Xu, G. J. Yang, G. W. Zhu, and B. Q. Qin, "Progress in nitrogen pollution research in Lake Taihu," Journal of Lake Sciences, vol. 26, no. 1, pp. 19-28, 2014.

[39] B. Gao, X. Y. Yan, X. S. Jiang, and C. P. Ti, "Research progress in estimation of agricultural sources pollution of the Lake Taihu region," Journal of Lake Sciences, vol. 26, no. 6, pp. 822-828, 2014.

[40] C. P. Ti, Y. Q. Xia, J. J. Pan, B. J. Gu, and X. Y. Yan, "Nitrogen budget and surface water nitrogen load in Changshu a case study in the Taihu Lake region of China," Nutrient Cycling in Agroecosystems, vol. 91, no. 1, pp. 55-66, 2011.

[41] Jiangsu Provincial Academy of Environmental Science, Technical Specification of Water Environment Comprehensive Treatment Plan about the Main Rivers in Lake Tailu Basin, Jiangsu Provincial Academy of Environmental Science, Jiangsu, China, 2008.

[42] R. R. Yan, J. Y. Chao, L. Zhang, Y. X. Cui, and W. Zhuang, "Research on the load of industrial pollution in the Taihu Lake Basin in Jiangsu Province," China Rural Water and Hydropower, vol. 3, pp. 39-43, 2012.

[43] R. G. Li, Y. L. Xia, A. Z. Wu, and Y. S. Qian, "Pollutants sources and their discharging amount in Taihu Lake area of Jiangsu Province," Journal of Lake Science, vol. 12, no. 2, pp. 147-153, 2000.

[44] Z. Liu, W. X. Li, Y. M. Zhang et al., "Estimation of non-point source pollution load in Taihu Lake Basin," Journal of Ecology and Rural Environment, vol. 26, no. 1, pp. 45-48, 2000.

[45] H. Zhang, H. P. Li, X. Y. Li, and Z. F. Li, “Temporal changes of nitrogen balance and their driving factors in typical agricultural area of Lake Taihu Basin," Chinese Journal of Soil Science, vol. 45, no. 5, pp. 1119-1129, 2014.

[46] N. Zhang, Y. H. Wang, Y. Qiu et al., "Quantification and environmental effects of waste nitrogen in crop-livestockhousehold system of Suzhou city," Soils, vol. 49, no. 5, pp. 926-934, 2017.

[47] X. Z. Wang, J. G. Zhu, R. Gao, and C. J. H. Bao, “Dynamics and ecological significance of nitrogen wet-deposition in Taihu Lake region-taking Changshu agro-ecological experiment station as an example," Chinese Journal of Applied Ecology, vol. 15, no. 9, pp. 1616-1620, 2004.

[48] Y. Zhang, X. J. Liu, A. Fangmeier, K. T. W. Goulding, and F. S. Zhang, "Nitrogen inputs and isotopes in precipitation in the North China Plain," Atmospheric Environment, vol. 42, no. 7, pp. 1436-1448, 2008.

[49] D. N. Zheng, X. S. Wang, S. D. Xie, L. Duan, and D. S. Chen, "Simulation of atmospheric nitrogen deposition in China in 2010," China Environmental Science, vol. 34, no. 5, pp. 1089-1097, 2014.

[50] Y. X. Xie, Z. Q. Xiong, G. X. Xing, X. Y. Yan, and S. L. Shi, "Source of nitrogen in wet deposition to a rice agroecosystem at Tai lake region," Atmospheric Environment, vol. 42, no. 21, pp. 5182-5192, 2008.

[51] Y. Wang, N. K. Liu, and J. F. Wang, "Study on atmospheric deposition of nitrogen and phosphorus in Taihu Lake," 
Environmental Science and Management, vol. 40, no. 5, pp. 103-105, 2011.

[52] J. F. Wang, K. J. Zhou, and X. Q. Wang, "Atmospheric nitrogen and phosphorous deposition in Hangjiahu area," China Environmental Science, vol. 35, no. 9, pp. 2754-2763, 2015.

[53] X. M. Ye, J. M. Hao, and L. Duan, "On critical loads of nutrient nitrogen deposition for some major lakes in China," Environmental Pollution and Control, vol. 24, no. 1, pp. 54-58, 2002. 

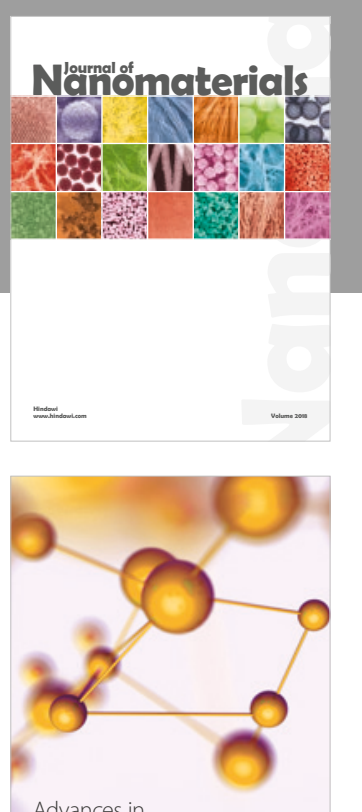

Physical Chemistry
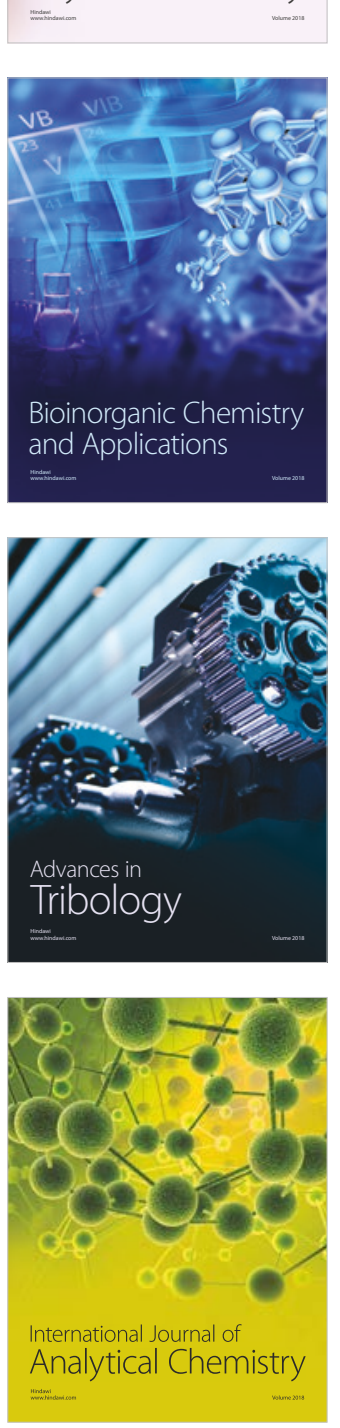

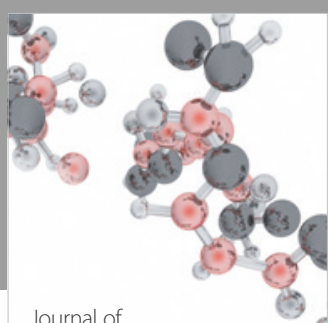

Analytical Methods

in Chemistry

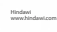

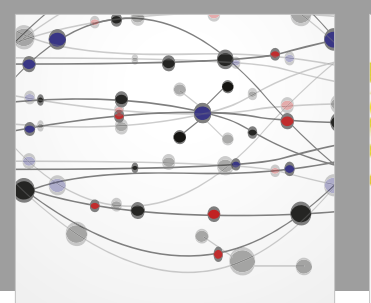

The Scientific World Journal

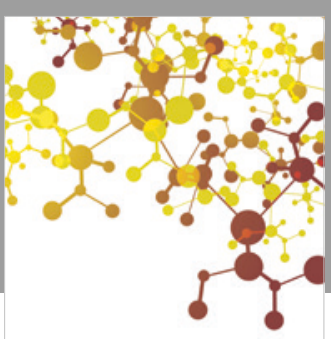

Journal of

Applied Chemistry
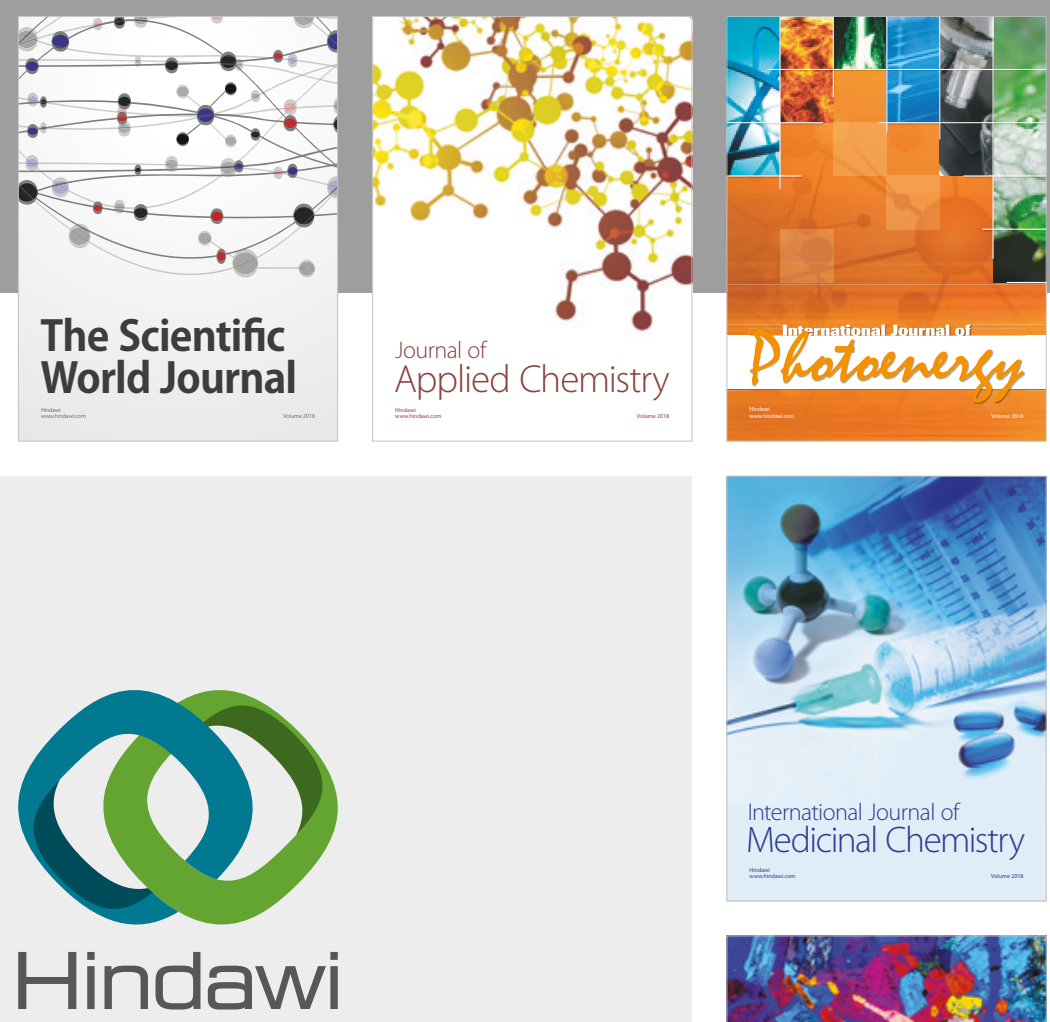

Submit your manuscripts at

www.hindawi.com
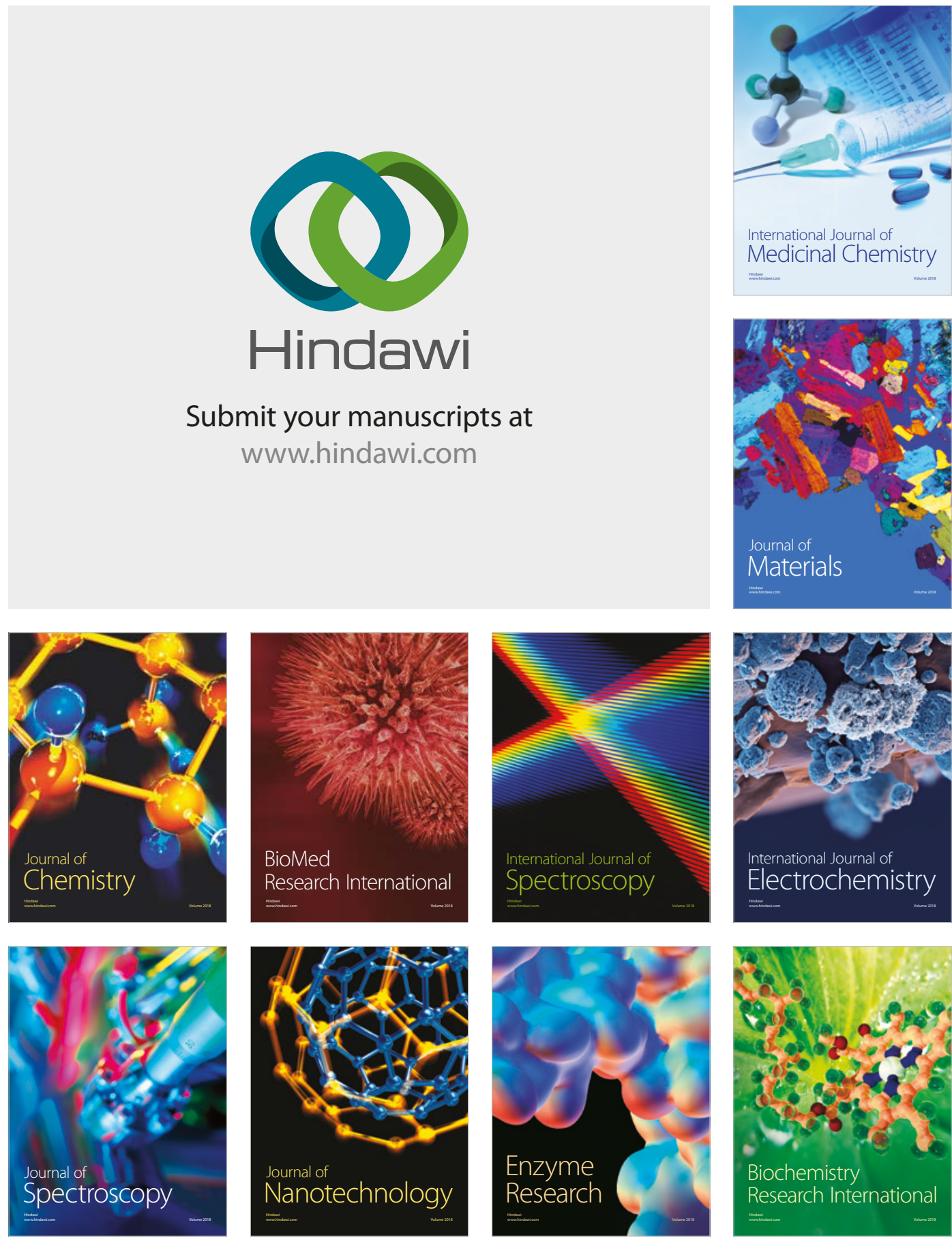
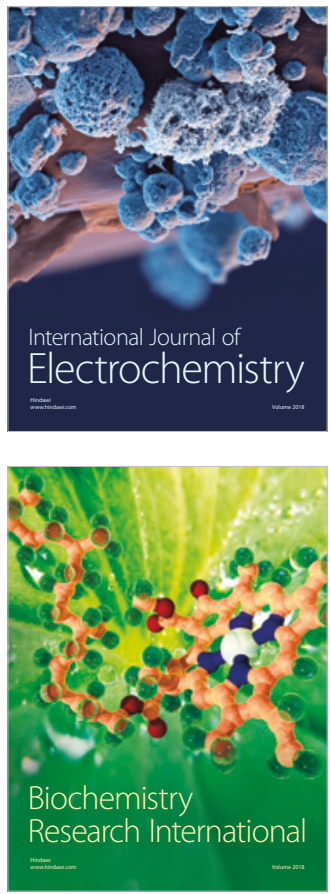